\title{
Response of precipitation over Greenland and the adjacent ocean to North Pacific warm spells during Dansgaard-Oeschger stadials
}

\author{
Thorsten Kiefer, ${ }^{1}$ Stephan Lorenz, ${ }^{2}$ Michael Schulz, ${ }^{1,3}$ Gerrit Lohmann, ${ }^{3,4}$ Michael Sarnthein ${ }^{1}$ \\ and Henry Elderfield ${ }^{5}$ \\ ${ }^{1}$ Institut für Geowissenschaften, Universität Kiel, Olshausenstrasse 40, 24118 Kiel, ${ }^{2}$ Max-Planck Institut für Meteorologie, Hamburg, \\ ${ }^{3}$ Meteorologisches Institut, Universität Hamburg, Hamburg, ${ }^{4}$ Fachbereich Geowissenschaften, Universität Bremen, Bremen, Germany; \\ ${ }^{5}$ Department of Earth Sciences, University of Cambridge, Cambridge, UK
}

\begin{abstract}
Palaeoceanographic reconstructions from the North Atlantic indicate massive ice breakouts from East Greenland near the onset of cold Dansgaard-0eschger (D-0) stadials. In contrast to these coolings in the North Atlantic area, a new sea-surface temperature record reveals concomitant warm spells in the northern North Pacific. A sensitivity experiment with an atmospheric general circulation model is used to test the potential impact of sea-surface warmings by $3.5{ }^{\circ} \mathrm{C}$ in the North Pacific, on top of otherwise cold stadial climate conditions, on the precipitation regime over the Northern Hemisphere ice
\end{abstract}

\begin{abstract}
sheets. The model predicts a maximum response over East Greenland and the Greenland Sea, where a $40 \%$ increase in net annual snow accumulation occurs. This remote effect of North Pacific warm spells on the East Greenland snow-accumulation rate may play an important role in generating $\mathrm{D}-0$ cycles by rebuilding the ice lost during ice breakouts. In addition, the increased precipitation over the Greenland Sea may help to sustain the D-O stadial climate state.
\end{abstract}

Terra Nova, 14, 295-300, 2002

\section{Introduction}

The climate of the last glacial period is characterized by strong variability on millennial timescales with rapid transitions between cold DansgaardOeschger (D-O) stadials and warm interstadials in the North Atlantic region. These climate fluctuations were first recognized in ice-core records from Greenland (Dansgaard et al., 1993; Grootes et al., 1993; Fig. 1) and North Atlantic deep-sea records (Bond et al., 1993), and were best developed during marine-isotope stages 3 and 4 [ 31-74 kyr BP (thousand years before present)], where they typically occurred every 1470 years (Grootes and Stuiver, 1997) or multiples thereof (Alley et al., 2001; Schulz, 2002). The global significance of the D-O climate variations was established by Clark et al. (1999) and Voelker et al. (2002). Moreover, palaeoceanographic data suggest that transitions between D-O stadials and interstadials are tied to variations in the mode of the large-scale oceanic thermohaline circulation, driven by

Correspondence: Thorsten Kiefer, Department of Earth Sciences, University of Cambridge, Cambridge CB2 3EQ, UK. Tel.: + 441223 333442; e-mail: tkie02@esc. cam.ac.uk changes in the rate of North Atlantic Deep Water (NADW) formation (Sarnthein et al., 1994; Alley et al., 1999, 2001).

Sediment records from the North Atlantic indicate that the reduction of NADW formation at the onset of each D-O stadial was driven mainly by massive ice breakouts from East Greenland, Iceland and, possibly, the Arctic, which injected meltwater close to the most prominent convection cells in the NW Atlantic and thereby inhibited NADW formation via enhanced stratification of the surface ocean (Voelker, 1999; van Kreveld et al., 2000; Elliot et al., 2002; in contrast to Grousset et al. 2000). The recurrent ice breakouts require an ongoing replenishment of the 'lost' ice between any subsequent breakouts, because the integrated effect of the breakouts did not ensue a significant long-term decrease in the Greenland ice-sheet volume during marine-isotope stages 3 and 4 (Funder et al., 1998). This replenishment was either constrained to the $\mathrm{D}-\mathrm{O}$ interstadials or continued over the complete D-O stadial-to-interstadial cycles.

Today, the entire North Atlantic provides approximately $28-46 \%$ of the moisture for the snowfall over Greenland, while only $8-13 \%$ originate from the North Pacific (Charles et al., 1994; Werner et al., 2001). During $\mathrm{D}-\mathrm{O}$ stadials, reduced sea-surface temperatures (SST) in the North Atlantic (Sarnthein et al., 2001; van Kreveld et al., 2000) led to a decrease in net evaporation and hence, to reduced moisture advection from this important source region to Greenland (Lohmann and Lorenz, 2000). The ensuing reduction in snowfall over Greenland has impeded a stadial replenishment of the ice sheet and, thus, requires an additional oceanic moisture source outside the North Atlantic. In contrast to today (Charles et al., 1994; Werner et al., 2001), the North Pacific may have played a more important role in delivering moisture to Greenland during D-O stadials. A recent reconstruction of sea-surface temperatures in the subarctic NW Pacific indicates a persistent pattern of warming during D-O stadials (Kiefer et al., 2001). Accordingly, NW Pacific SST variations have been in antiphase during the course of a D-O cycle with those in the northern North Atlantic. This interoceanic phasing may be linked either to dominant atmospheric (e.g. Hoskins and Karoly, 1981) or to oceanic forcing. Recently, Kiefer et al. (2001) found evidence for the latter; that is, weakened NADW formation during $\mathrm{D}-\mathrm{O}$ stadials entailed reduced upwelling of 


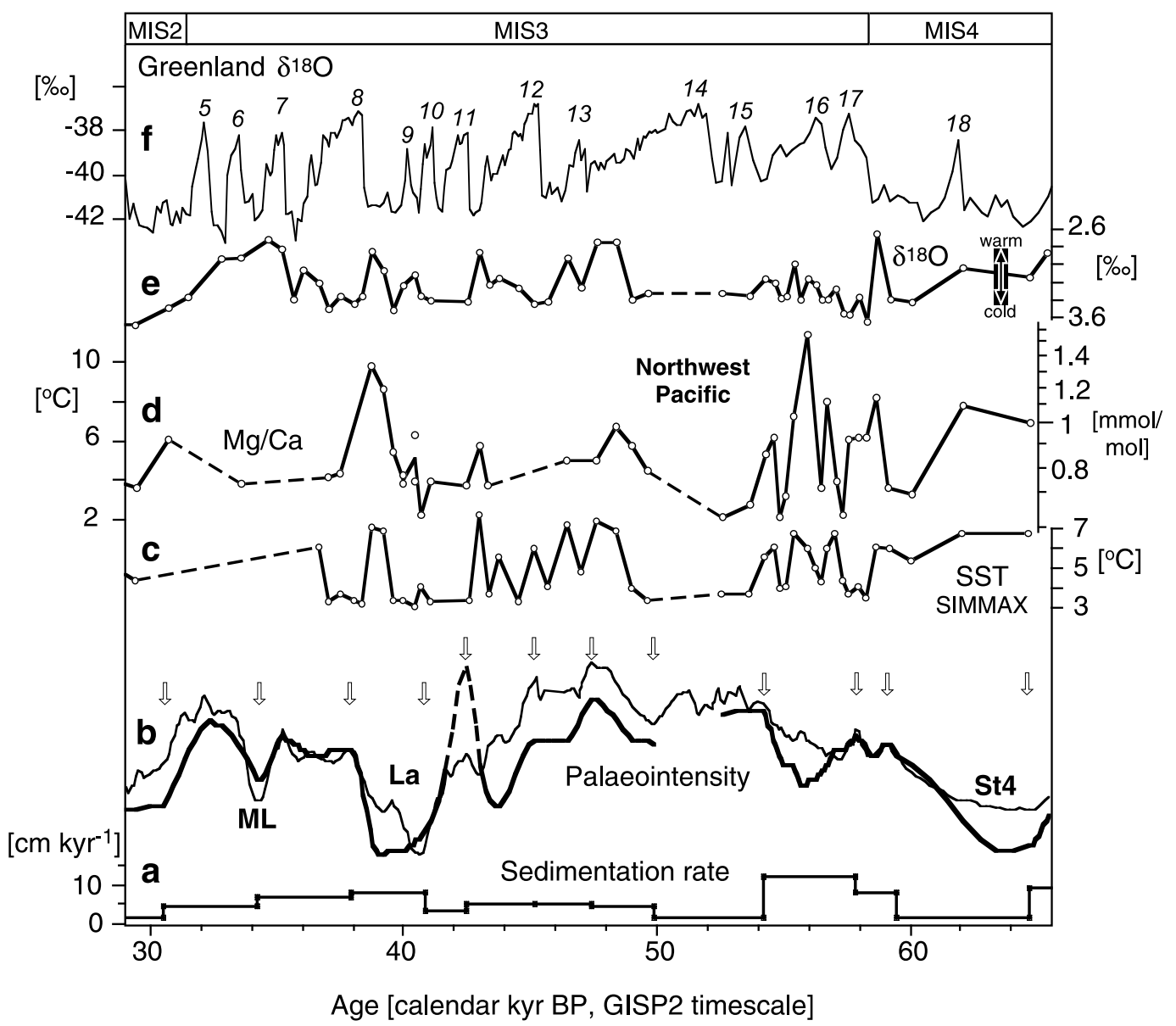

Fig. 1 Sea-surface temperature (SST) (c-e), sedimentation rates (a), and geomagnetic palaeointensity records (b) at subarctic NW Pacific ODP Site 883 between 29000 and 65000 calendar yr BP compared to (f) the GISP2 $\delta^{18}$ O temperature record (Grootes and Stuiver, 1997). The age model is based on tie points (arrows) in geomagnetic palaeointensity record at ODP Site 883 (bold line), being tuned to the NAPIS-75 stacked record (thin line) from the North Atlantic $\left(r^{2}=0.58\right.$; Kiefer et al. 2001). Mono Lake (ML), Laschamp (L), and late-stage 4 (St4) are prominent palaeointensity minima. (c) SST for summer, estimated from planktonic foraminiferal assemblages by means of the SIMMAX transfer function (Pflaumann et al., 1996). (d) $\mathrm{Mg} / \mathrm{Ca}$ ratios and deduced SST from N. pachyderma (s.), calibrated after Elderfield and Ganssen (2000). (e) Planktonic $\delta^{18} \mathrm{O}$ values of $N$. pachyderma (s.) plotted on a palaeotemperature-equivalent scale according to Shackleton (1974). Marine isotope stages (MIS) 2-4 and curves (a-c) and (e) after Kiefer et al. (2001). Gaps in SST records result from lack of foraminifera specimens.

cold deep water in the North Pacific, resulting in a relative warming of the surface ocean.

The North Pacific warming during D-O stadials may have led to a significant increase in evaporation in this high-latitude region. Because it lies in the westerlies, upwind of Greenland, this evaporation may have entailed increased moisture transport to the northern North Atlantic and more snowfall over Greenland, partially compensating for the outlined deficit in moisture supply from the cooled North Atlantic during D-O stadials. In this study, the stadial-tointerstadial SST anomalies in the sub- arctic NW Pacific are documented and employed as boundary condition for an atmospheric general circulation model to quantify the potential effect of syn-stadial North Pacific warm spells on the net precipitation over Greenland and the adjacent ocean.

\section{Chronology and amplitude of North Pacific warm spells}

The centennial-scale SST record for this study was first established at Ocean Drilling Program (ODP) Site 883 from the subarctic NW Pacific $\left(51^{\circ} \mathrm{N}, 168^{\circ} \mathrm{E} ; 2385 \mathrm{~m}\right.$ water depth; Kiefer et al. 2001). Because this region constitutes the terminus of the deep path of global thermohaline circulation, its SST changes are strongly affected by variations in the upwelling intensity of cold Pacific deep water (Reid, 1965; Gordon, 1991). It is surmised that the surface water record at ODP Site 883 may represent analogous hydrographic changes over the entire subarctic North Pacific. This is confirmed by a parallel SST trend found in the northeasternmost Pacific (de Vernal and Pedersen, 1997).

At ODP Site 883, the submillennialscale chronology of the last 25-80 kyr is based mainly on tuning the geomagnetic palaeointensity curve (Roberts 
CTRL: Annual P-E $[\mathrm{cm} / \mathrm{y}]$

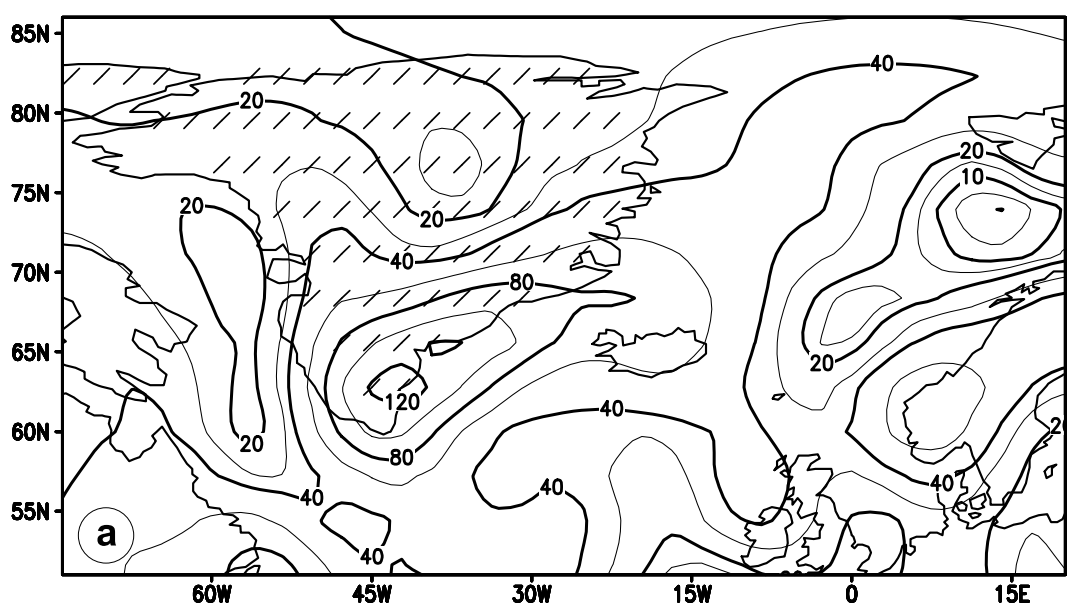

LGM (CLIMAP): Annual P-E [cm/y]

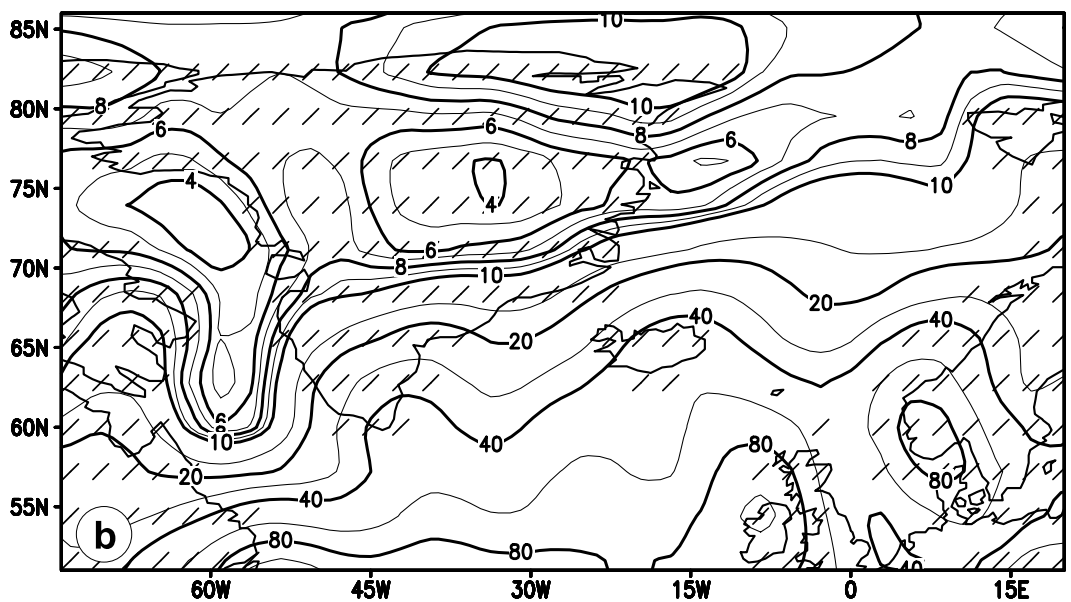

N-Pacific warm spell: Annual P-E anomaly from CLIMAP $[\mathrm{cm} / \mathrm{y}]$

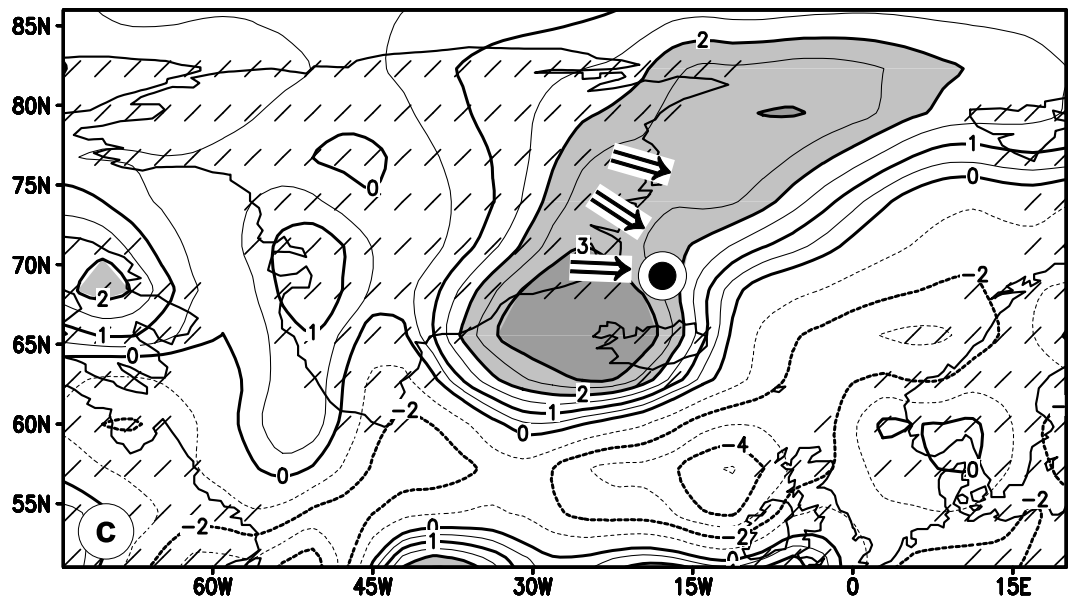

et al., 1997) to a stacked geomagnetic record from the North Atlantic (NAPIS75; Laj et al., 2000). Unlike
Fig. 2 (a) Modelled annual mean precipitation minus evaporation $(P-E)$ (in $\left.\mathrm{cm} \mathrm{yr}^{-1}\right)$ in the North Atlantic region for the modern control experiment. Extent of continental ice sheets is hatched. (b) As (a), but for glacial experiment based on CLIMAP (1981) SST. (c) Annual $P-E$ anomaly for the experiment with $3.5^{\circ} \mathrm{C}$ warming in the northern North Pacific relative to the glacial run. Positive values denote higher $P-E$ than in glacial run (b). Shading highlights anomalies above $2 \mathrm{~cm} \mathrm{yr}^{-1}$ (light) and $3 \mathrm{~cm} \mathrm{yr}^{-1}$ (dark). Arrows at the east coast of Greenland indicate probable source (fjord) regions of major ice breakouts; encircled bullet marks glacial convection area (cf. Sarnthein et al. 2001). Contour lines were smoothed with a nine-point filter.

and late stage-4 magnetic minima form key age control points on the GISP2 timescale (arrows in Fig. 1) with a precision better than $500 \mathrm{yr}$ (Kiefer et al., 2001), which enables distinction between in-phase and antiphase climatic trends within a generally 1500-yr-long D-O cycle.

On the basis of oxygen isotope $\left(\delta^{18} \mathrm{O}\right)$ data and species counts of planktonic foraminifera (time resolution of 250-800 yr), the NW Pacific stadial-interstadial SST differences reach $2.5-4.0{ }^{\circ} \mathrm{C}$ (Fig. 1). As $\delta^{18} \mathrm{O}$ derived SST estimates may be biased by meltwater injections and the quality of faunal-based SST estimates in cold water is limited by low faunal diversity, the range of SST variations was tested by means of $\mathrm{Mg} / \mathrm{Ca}$ ratios in foraminiferal calcite. They are temperature dependent owing to the partitioning of $\mathrm{Mg}$ during calcification (Nürnberg et al., 1996).

Analysis was carried out for $\mathrm{Mg} / \mathrm{Ca}$ ratios of the planktonic foraminifera Neogloboquadrina pachyderma (left coiling), which in some ocean regions - particularly in upwelling regions with an absent or shallow thermocline - reflect temperatures near to the sea surface (Elderfield and Ganssen, 2000); in well-stratified regions they rather average subsurface temperatures down to $200 \mathrm{~m}$ (Simstich, 1999). Between 22 and 54 tests were picked for each $\mathrm{Mg} / \mathrm{Ca}$ analysis from the $150-250-\mu \mathrm{m}$ size fraction. After sonication, cleaning and dilute acid polishing, samples were analysed 
with a Varian Vista inductively coupled plasma optical emission spectrometer (Elderfield and Ganssen, 2000) at the Department of Earth Sciences, Cambridge. $\mathrm{Mg} / \mathrm{Ca}$ ratios were converted into temperature estimates $\left( \pm 0.6{ }^{\circ} \mathrm{C}\right)$ using the speciesspecific calibration of Elderfield and Ganssen (2000).

The $\mathrm{Mg} / \mathrm{Ca}$-based SST excursions generally confirm the SST trends and even exceed the oscillations over $\mathrm{D}-\mathrm{O}$ cycles found in the $\delta^{18} \mathrm{O}$ - and faunaderived SST estimates (Fig. 1; Kiefer et al., 2001). Most pronounced $\mathrm{Mg} / \mathrm{Ca}$ temperature shifts reach $6-8{ }^{\circ} \mathrm{C}$ prior to $\mathrm{D}-\mathrm{O}$ interstadial (IS) 8 and subsequent to D-O IS 16. SST changes of $3.5-4.5^{\circ} \mathrm{C}$ occur prior to D-O IS 15, 16, and 17. Other SST maxima in the planktonic $\delta^{18} \mathrm{O}$ and faunal records, such as prior to IS 1113 , remain undetected in the $\mathrm{Mg} / \mathrm{Ca}$ SST record because of insufficient foraminifera specimens in these core sections. A potential effect of differential dissolution on $\mathrm{Mg} / \mathrm{Ca}$-based SST changes is largely irrelevant, because high foraminifera dissolution just parallels the abundance of $\mathrm{Mg}$ (Kiefer et al., 2001).

In summary, the $\mathrm{Mg} / \mathrm{Ca}$ data corroborate that the subarctic surface water in the NW Pacific warmed by as much as $3.5-8.0^{\circ} \mathrm{C}$ during $\mathrm{D}-\mathrm{O}$ stadials, when the North Atlantic region experienced a pronounced cooling as documented by the $\delta^{18} \mathrm{O}$ decrease in the GISP2 ice core record (Fig. 1). This supports the outlined antiphase SST pattern between the northern North Atlantic and the subarctic NW (and NE; de Vernal and Pedersen, 1997) Pacific. More prominent $\mathrm{Mg} / \mathrm{Ca}$-based SST variations of $6-8{ }^{\circ} \mathrm{C}$ may reflect the conditions near the sea surface (top $50 \mathrm{~m}$ ), whereas weaker faunal-based SST shifts of $2.5-4.0{ }^{\circ} \mathrm{C}$ may rather record the integrated temperature shifts of the entire surface layer inhabited by planktonic foraminifera.

\section{Precipitation response over Greenland to North Pacific warm spells}

Numerical climate models consitute the only way to predict how a warm spell in the northern North Pacific will affect precipitation over the North Atlantic region during a $\mathrm{D}-\mathrm{O}$ stadial.
Here, a modelled state of glacial climate, which may come close to a $\mathrm{D}-\mathrm{O}$ stadial, is perturbed by adding the (reconstructed) positive stadial SST anomalies in the North Pacific.

The global atmospheric general circulation model employed (acronym ECHAM3; Roeckner et al., 1992) is based on the standard hydrodynamic equations and includes a full set of physical processes. Note that the ECHAM3 model considers an explicit hydrological cycle including formation and transport of water, partitioning of liquid/ice phase with precipitation of snow and evaporation of cloud water and raindrops. The model resolution is 19 hybrid layers in the vertical and approximately $2.8^{\circ} \times 2.8^{\circ}(\mathrm{T} 42)$ in the horizontal. Lohmann and Lorenz (2000) used this model to study the hydrological cycle during the Last Glacial Maximum (LGM), employing the boundary conditions defined by the Palaeoclimate Modelling Intercomparison Project (PMIP, 2000). These include information on orography, land-sea distribution, sea-ice extent and ice-sheet geometry, as well as vegetation, albedo and SST. Specifically, prescribed seasonal SST data are based on the CLIMAP (1981) reconstruction, atmospheric $\mathrm{CO}_{2}$ concentration is set to 200 ppmv (Barnola et al., 1987), icesheet elevation is taken from Peltier (1994), and sea level is lowered by $120 \mathrm{~m}$ relative to today (details in Lohmann and Lorenz, 2000).

Because no palaeoclimatic reconstructions exist for $\mathrm{D}-\mathrm{O}$ stadials on a global scale to provide boundary conditions for ECHAM3, the LGM model simulation was employed as surrogate for a generic $\mathrm{D}-\mathrm{O}$ stadial of marine isotope stage 3 . This approach is justified because: (i) atmospheric $\mathrm{CO}_{2}$ during stage 3 was within 20 ppmv of the LGM value (Barnola et al., 1987); (ii) the ice sheets, although of variable specific geometry (Kirby and Andrews, 1999), almost reached the spatial extent of the LGM (Marshall and Clarke, 1999); accordingly, (iii) the sea level was already lowered by $55-95 \mathrm{~m}$ ice-volume equivalent below its modern level (Lambeck and Chappell, 2001), and (iv) various SST records indicate a cooling to a degree close to or even below that of the LGM (Lea et al., 2000; Sarnthein et al., 2001).
The anomalous North Pacific warm spell is parameterized by increasing the LGM SST for each month uniformly by $3.5^{\circ} \mathrm{C}$ over the entire North Pacific between 49 and $57^{\circ} \mathrm{N}$. In order to avoid steep meridional SST gradients, the step-like anomaly was tapered over two grid rows on each side near $49^{\circ}$ and $57^{\circ} \mathrm{N}$. The anomaly of $3.5^{\circ} \mathrm{C}$ corresponds to the lower end of the range of reconstructed shifts from $\mathrm{Mg} / \mathrm{Ca}$ palaeothermometry and therefore constitutes a conservative estimate. Because the SST values do not show any large zonal gradient across the North Pacific, either in the LGM or today, and because of the additional, parallel SST record established by de Vernal and Pedersen (1997) in the NE Pacific, it is considered legitimate to extrapolate the SST variation along a complete zonal belt extending from the northwestern to the northeastern Pacific. The reduced upwelling of deep water in the northern North Pacific, which is regarded responsible for the warm spells (Kiefer et al., 2001), is likely to affect the entire width of the North Pacific. The ECHAM3 model was integrated over 15 model years, starting from the unperturbed glacial state (Experiment LGM.O of Lohmann and Lorenz, 2000). Results presented below average quantities of the last 10 model years.

For the control integration, forced by present-day conditions, modelled net annual snow accumulation over Greenland (Fig. 2a) agrees by and large with observational data, for example, near Greenland summit, where the predicted accumulation rate is consistent with measured $30 \mathrm{~cm} \mathrm{yr}^{-1}$ (Ohmura and Reeh, 1991; note that the modelled precipitation rates are given in water equivalents which are almost identical to ice accumulation rates). The bulk annual precipitation occurs during summer (seasonal variations not shown). Without the North Pacific warm spell (Fig. 2b) the model predicts a low annual net precipitation in the range of 3-11 $\mathrm{cm} \mathrm{yr}^{-1}$, and an average value of $5 \mathrm{~cm} \mathrm{yr}^{-1}$ in the source area of the ice breakouts from East Greenland (arrows in Fig. 2c). In central Greenland the glacial accumulation rate is reduced by $75 \%$ relative to today, identical with GISP2-derived data (Cuffey and Clow, 1997).

Experiment three, which employs increased SST in the North Pacific 
(Fig. 2c), indicates a distinct remote effect of the North Pacific SST rise on precipitation in the North Atlantic region, an effect which is most pronounced in East Greenland and the adjacent Greenland Sea (Fig. 2c). This area is crucial for deep-water formation in the glacial North Atlantic (Sarnthein et al., 1995; 2001; Lohmann and Schulz, 2000). Compared to the glacial run (Fig. 2b), net annual precipitation increases considerably by up to $4 \mathrm{~cm} \mathrm{yr}^{-1}$ and an average value of $2 \mathrm{~cm} \mathrm{yr}^{-1}$ over East Greenland, corresponding to approximately $40 \%$ of glacial precipitation. However, in the vicinity of the Greenland summit the effect of a North Pacific warm spell on net precipitation remains negligible (Fig. 2c), consistent with the small variability of GISP2 derived ice accumulation rates over D-O cycles (Cuffey and Clow, 1997).

\section{Implications for Dansgaard- Oeschger climate variations}

The modelled precipitation changes over Greenland and the adjacent ocean region may affect $\mathrm{D}-\mathrm{O}$ climate variability in two different ways. The $40 \%$ precipitation increase over East Greenland, as response to the $\mathrm{D}-\mathrm{O}$ stadial warm spells in the northern North Pacific, contributes to an efficient replenishment of the ice sheet on East Greenland during time intervals within which the moisture supply from the North Atlantic was reduced. Accordingly, the effect of North Pacific warm spells on precipitation over Greenland may accelerate the early rebuilding of the East Greenland ice sheet prior to the next ice breakout. Because this rebuilding is an indispensable prerequisite for the observed succession of $\mathrm{D}-\mathrm{O}$ cycles (van Kreveld et al., 2000), including the sea-level lowering subsequent to the breakouts (Chappell, 2002), the contribution of the North Pacific moisture source to the East Greenland ice sheet may constitute an additional, but crucial component in the generation of D-O cycles. Moreover, increased net precipitation over the glacial convection areas in the Greenland Sea during $\mathrm{D}-\mathrm{O}$ stadials helps sustain an already existing density stratification of the surface ocean, which is responsible for reduced deep-water formation. Thus, the
North Pacific warm spells provide an important positive feedback mechanism for millennial-scale climate change, which helps keeping the climate system in the stadial state. Further sensitivity studies with a model of the ocean-atmosphere-cryosphere system may lead to a better understanding of the interplay between the Atlantic and Pacific oceans and its effect on climate variability.

\section{Acknowledgments}

We greatly appreciate fruitful discussions with P. Grootes. The Ocean Drilling Program (ODP) is acknowledged for providing abundant sample material. This work was supported by the Deutsche Forschungsgemeinschaft through grant Sa 39/2 (TK) and the Bundesministerium für Bildung und Forschung through the DEKLIMProject 'Climate Transitions' (GL, MSch). The manuscript was much improved by valuable reviews of J. Andrews, E. Jansen, and J. Mayewski.

\section{References}

Alley, R.B., Clark, P.U., Keigwin, L.D. and Webb, R.S., 1999. Making sense of millennial-scale climate change. In: Mechanisms of Global Climate Change at Millennial Time Scales (P. U. Clark et al., eds). Geophys. Monogr., 112, 385-394.

Alley, R.B., Anandakrishnan, S. and Jung, P., 2001. Stochastic resonance in the North Atlantic. Paleoceanography 16, 190-198.

Barnola, J.M., Raynaud, D., Korotchevich, Y.S. and Lorius, C., 1987. Vostok ice core provides 160,000 -year record of atmospheric $\mathrm{CO}_{2}$. Nature, 329, 408-414.

Bond, G., Broecker, W., Johnsen, S. et al., 1993. Correlations between climate records from North Atlantic sediments and Greenland ice. Nature, 365, 143-147.

Chappell, J., 2002. Sea level changes forced ice breakouts in the last glacial cycle. new results from coral terraces. Quat. Sci. Rev., 21, 1229-1240.

Charles, C.D., Rind, D., Jouzel, J., Koster, R.D. and Fairbanks, R.G., 1994 Glacial-interglacial changes in moisture sources for Greenland: influences on the ice core record of climate. Science, $\mathbf{2 6 3}$, 508-511.

Clark, P.U., Webb, R.S. and Keigwin, L.D., 1999. Mechanisms of Global Climate Change at Millennial Time Scales. Geophys. Monogr., 112, 394.

CLIMAP Projekt Members, 1981. Seasonal reconstructions of the Earth's surface at the last glacial maximum.
Geol. Soc. Am. Map and Chart Ser., MC-36, 1-18.

Cuffey, K.M. and Clow, G.D., 1997. Temperature, accumulation, and ice sheet elevation in central Greenland through the last deglacial transition. J. Geophys. Res., 102, 26,383-26,396.

Dansgaard, W., Johnsen, S.J., Clausen, H.B. et al., 1993. Evidence for general instability of past climate from a 250-kyr ice-core record. Nature, 364, 218-220.

de Vernal, A. and Pedersen, T.F., 1997. Micropaleontology and palynology of core PAR87A-10. A 23,000 year record of paleoenvironal changes in the Gulf of Alaska, northeast North Pacific. Paleoceanography, 12, 821-830.

Elderfield, H. and Ganssen, G., 2000. Past temperature and $\delta^{18} \mathrm{O}$ of surface ocean waters inferred from foraminiferal $\mathrm{Mg} / \mathrm{Ca}$ ratios. Nature, 405, 442-445.

Elliot, M., Labeyrie, L. and Duplessy, J.-C., 2002. Changes in North Atlantic Deep-Water formation associated with the Dansgaard-Oeschger temperature oscillations (10-60 ka). Quat. Sci. Rev., 21, 1153-1163.

Funder, S., Hjort, C., Landvik, J., Nam, S., Reeh, N. and Stein, R., 1998. History of a stable ice margin - East Greenland during the middle and upper Pleistocene. Quat. Sci. Rev., 17, 77-123.

Gordon, A.L., 1991. The role of thermohaline circulation in global climate change. L-D. Earth Obs. Rep., 1990-91, 44-51.

Grootes, P.M. and Stuiver, M., 1997. Oxygen $18 / 16$ variability in Greenland snow and ice with $10^{-3}$ - to $10^{5}$-year time resolution. J. Geophys. Res., 102, 26,455-26,470.

Grootes, P.M., Stuiver, M., White, J.W.C., Johnsen, S. and Jouzel, J., 1993. Comparison of oxygen isotope records from the GISP2 and GRIP Greenland ice cores. Nature, 366, 552-554.

Grousset, F.E., Pujol, C., Labeyrie, L., Auffret, G. and Boelaert, A., 2000. Were the North Atlantic Heinrich events triggered by the behavior of the European ice sheets? Geology, 28, 123-126.

Hoskins, B. and Karoly, D., 1981. The steady linear response of a spherical atmosphere to thermal and orographic forcing. J. Atmos. Sci., 38, 1179-1196.

Kiefer, T., Sarnthein, M., Erlenkeuser, H., Grootes, P. and Roberts, A., 2001. North Pacific response to millennialscale changes in ocean circulation over the last $60 \mathrm{ky}$. Paleoceanography, 16, 179-189.

Kirby, M.E. and Andrews, J.T., 1999. MidWisconsin Laurentide Ice Sheet growth and decay. Implications for Heinrich events 3 and 4. Paleoceanography, 14, 211-223. 
van Kreveld, S., Sarnthein, M., Erlenkeuser, H. et al., 2000. Potential links between surging ice sheets, circulation changes, and the DansgaardOeschger cycles in the Irminger Sea, 60-18 kyr. Paleoceanography, 15, 425-442.

Lambeck, K. and Chappell, J., 2001. Sea level change through the last glacial cycle. Science, 292, 679-686.

Laj, C., Kissel, C., Mazaud, A., Channell, J.E.T. and Beer, J., 2000. North Atlantic paleointensity stack since 75 ka (NAPIS75) and the duration of the Laschamp event. Phil. Trans. R. Soc. A, 358, 1009-1025.

Lea, D.W., Pak, D.K. and Spero, H.J., 2000. Climate impact of late Quaternary equatorial Pacific sea surface temperature variations. Science, $\mathbf{2 8 9}$, 1719-1724.

Lohmann, G. and Lorenz, S., 2000. On the hydrological cycle under paleoclimatic conditions as derived from AGCM simulations. J. Geophys. Res., D105, 17,417-17,436.

Lohmann, G. and Schulz, M., 2000. Reconciling Bølling warmth with peak deglacial meltwater discharge. Paleoceanography, 15, 537-540.

Marshall, S.J. and Clarke, G.K.C., 1999. Modeling North American freshwater runoff through the last glacial cycle. Quat. Res., 52, 300-315.

Nurnberg, D., Bijma, J. and Hemleben, C., 1996. Assessing the reliability of magnesium in foraminiferal calcite as a proxy for water mass temperatures. Geochim. Cosmochim. Acta, 60, 803-814.

Ohmura, A. and Reeh, N., 1991. New precipitation and accumulation maps for Greenland. J. Glaciol., 37, 140-148.
Peltier, W.R., 1994. Ice age topography. Science, 265, 195-201.

Pflaumann, U., Duprat, J., Pujol, C. and Labeyrie, L.D., 1996. SIMMAX. A modern analog technique to deduce Atlantic sea surface temperatures from planktonic foraminifera in deep-sea sediments. Paleoceanogr., 11, 15-35.

PMIP (Paleoclimate Modeling Intercomparison Project), 2000. Proceedings of the third PMIP workshop, Canada, 4-8 October 1999 in WCRP-111, WMO/TD1007 (P. Braconnot et al., eds), pp. 271. World Meteorological Organization, Geneva.

Reid, J.L. Jr, 1965. Intermediate Waters of the Pacific Ocean. John Hopkins University Press, Baltimore, MD.

Roberts, A.P., Lehman, B., Weeks, R.J., Verosub, K.L. and Laj, C., 1997. Relative paleointensity of the geomagnetic field over the last 200,000 years from ODP sites 883 and 884, North Pacific Ocean. Earth Planet Sci. Lett., 152, 11-23.

Roeckner, E., Arpe, K., Bengtsson, L. et al., 1992. Simulation of the presentday climate with the ECHAM model: Impact of model physics and resolution. Max-Planck Institut F,R Meteorogie Report, 93, 1-172.

Sarnthein, M., Winn, K., Jung, S.J.A., Duplessy, J.C., Erlenkeuser, H. and Ganssen, G., 1994. Changes in east Atlantic deepwater circulation over the last 30,000 years: Eight time slice reconstructions. Paleoceanography, 9, 209-267. Sarnthein, M., Jansen, E., Weinelt, M. et al., 1995. Variations in Atlantic surface ocean paleoceanography, $50^{\circ}-85^{\circ} \mathrm{N}$. A time-slice record of the last 30,000 years. Paleoceanography, 10, 1063-1094.
Sarnthein, M., Stattegger, K., Dreger, D. et al., 2001. Fundamental modes and abrupt changes in North Atlantic circulation and climate over the last $60 \mathrm{ky}$. Concepts, reconstruction and numerical modeling. In: The Northern North Atlantic: a Changing Environment (P. Schäfer et al., eds), pp. 365-410. Springer, Berlin.

Schulz, M., 2002. On the 1470-year pacing of Dansgaard-Oeschger warm events. Paleoceanography, 17, 4-1-4-9.

Shackleton, N.J., 1974. Attainment of isotopic equilibrium between ocean water and the benthonic foraminifera genus Uvigerina. Isotopic changes in the ocean during the last glacial. Coll. Int. C. N. R. S., 219, 203-209.

Simstich, J., 1999. Die ozeanische Deckschicht des Europäischen Nordmeers im Abbild stabiler Isotope von Kalkgehäusen unterschiedlicher Planktonforaminiferenarten. Ber. Rep. Inst. Geowiss., Univ. Kiel, 2, 96.

Voelker, A.H.L., 1999. Zur Deutung der Dansgaard-Oeschger Ereignisse in ultrahochausenden Sedimentprofilen aus dem Europischen Nordmeer. Ber. Rep. Inst. Geowiss., Univ. Kiel, 9, 1-278.

Voelker, A.H.L. et al., 2002. Global distribution of centennial-scale records for marine isotope stage (MIS) 3: a database. Quat. Sci. Rev., 21, 1185-1212.

Werner, M., Heimann, M. and Hoffmann, G., 2001. Isotopic composition and origin of polar precipitation in present and glacial climate conditions. Tellus, 53B, 53-71.

Received 31 July 2001; revised version accepted 11 April 2002 